\title{
REVIEW
}

\section{The Deepwater Horizon oil spill marine mammal injury assessment}

\author{
Ryan Takeshita ${ }^{1}$, Laurie Sullivan ${ }^{2, *}$, Cynthia Smith $^{3}$, Tracy Collier ${ }^{4}$, Ailsa Hall ${ }^{5}$, \\ Tom Brosnan ${ }^{6}$, Teri Rowles ${ }^{7}$, Lori Schwacke ${ }^{8}$
}

\author{
${ }^{1}$ Abt Associates Inc., Boulder, CO 80302, USA \\ ${ }^{2}$ National Oceanic and Atmospheric Administration, Assessment and Restoration Division, Office of Response and Restoration, \\ Santa Rosa, CA 95404, USA \\ ${ }^{3}$ National Marine Mammal Foundation, San Diego, CA 92106, USA \\ ${ }^{4}$ Joint Office for Science Support, University Corporation for Atmospheric Research, Boulder, CO 80301, USA \\ ${ }^{5}$ Sea Mammal Research Unit, Scottish Oceans Institute, University of St. Andrews, St. Andrews, UK \\ ${ }^{6}$ National Oceanic and Atmospheric Administration, Assessment and Restoration Division, Office of Response and Restoration, \\ Silver Spring, MD 20910, USA \\ ${ }^{7}$ National Oceanic and Atmospheric Administration, National Marine Fisheries Service, Office of Protected Resources, \\ Silver Spring, MD 20910, USA \\ ${ }^{8}$ National Oceanic and Atmospheric Administration, National Centers for Coastal Ocean Science, Charleston, SC 29412, USA
}

\begin{abstract}
From 2010 to 2015, a team of scientists studied how the BP Deepwater Horizon (DWH) oil spill affected marine mammals inhabiting the northern Gulf of Mexico, as part of the DWH Natural Resource Damage Assessment process. The scientists conducted the assessment on behalf of the DWH co-Trustees, with the purpose of investigating whether marine mammals were exposed to DWH oil and what types of injuries they suffered as a result of the DWH oil exposure, and then quantifying those injuries to determine the appropriate amount of restoration required to offset the injuries. Photographs, aerial surveys, spatial analyses of the co-occurrence between surface slick and cetacean populations, and chemical fingerprinting of oiled and stranded carcasses all confirm that at least 15 cetacean species were exposed to the DWH surface slick. Cetaceans that encountered the slick likely inhaled, aspirated, ingested, and/or adsorbed oil. In this Theme Section, marine mammal biologists, statisticians, veterinarians, toxicologists, and epidemiologists describe and quantify the adverse effects of this oil exposure. Taken together, this combination of oil spill dynamics, veterinary assessments, pathological, spatial, and temporal analyses of stranded animals, stock identification techniques, population dynamics, and a broad set of coordinated modeling efforts is an unprecedented assessment of how a major oil spill impacted a large and complex marine mammal community and their connected habitats.
\end{abstract}

KEY WORDS: Deepwater Horizon · Marine mammals · Oil · Petroleum · Natural Resource Damage Assessment $\cdot$ Exposure $\cdot$ Injury assessment

\section{BACKGROUND}

From the early days of the Deepwater Horizon (DWH) oil spill, it was clear that the disaster presented unique challenges of magnitude and nature.
It was the first time that US Government authorities declared a 'Spill of National Significance': a spill so severe and complex that it requires an 'extraordinary coordination of federal, state, local, and responsible party resources' (40 C.F.R. § 300.5). Gov- 
ernment and industry stakeholders had to confront a blowout in deep water $65 \mathrm{~km}$ offshore, respond to a widespread surface oil slick with a constant source, survey a 3-dimensional footprint with a diverse range of habitats and natural resources, and apply regulatory statutes (such as the Oil Pollution Act and the National Oil and Hazardous Substances Pollution Contingency Plan) across a long timeline. A critical concern for the team of DWH federal and state Trustees to address was how the oil spill affected the 22 species of marine mammals in the northern Gulf of Mexico (nGoM).

This Theme Section describes much of the technical work that helped the DWH Trustees evaluate the impact of the DWH spill on marine mammals. The Trustees' Natural Resource Damage Assessment (NRDA) is described in the Programmatic Damage Assessment and Restoration Program/Programmatic Environmental Impact Statement (PDARP/PEIS) (DWH NRDA Trustees 2016). In this overview paper, our goal was to (1) describe the elements of the assessment that informed how and to what extent nGoM marine mammals were exposed to DWH oil, and (2) provide the reader with a broader context for each of the papers in this Theme Section, as well as manuscripts published elsewhere, and how they fit into the overall marine mammal assessment.

This Theme Section is not meant to be a complete catalog of the studies undertaken or considered by the DWH Trustees, nor should the results be interpreted to represent a 'final' description of the shortand long-term harm to nGoM marine mammals. Scientists who contributed to the NRDA as well as scientists working outside of the NRDA continue to investigate how the DWH oil spill has affected and may continue to affect nGoM marine mammals.

\section{SCIENTIFIC APPROACH IN THE CONTEXT OF NRDA}

In the wake of the Exxon Valdez oil spill in 1989, the US government passed the Oil Pollution Act of 1990 (OPA), which prompted government agencies to develop regulatory language to formalize the prevention, response, liability, and compensation associated with oil pollution in US waters. Under the OPA, parties responsible for oil spills must compensate the public for the harm that the discharged oil causes to natural resources, and that compensation must be used to restore those resources that were harmed. The National Oceanic and Atmospheric Administration (NOAA) has issued guidance to natural resource
Trustees for conducting an oil spill NRDA (Huguenin et al. 1996). The guidance for the NRDA process lays out the technical requirements to demonstrate that a specific incident has caused harm ('injuries') to natural resources, and in turn, how the Trustees propose to restore the resources that were injured. For each resource affected by the DWH oil spill, including marine mammals, the Trustees and their technical experts evaluated:

- How were the resources exposed to DWH oil? When, where, to what degree, and for how long? Is there a reasonable pathway by which DWH oil moved from the source of the oil at the well site to the site of exposure?

- What types of injuries did DWH oil (and the associated response activities) cause to the resources? For organisms, is there evidence that DWH oil caused mortality, reproductive effects, and/or adverse health effects?

- What is the magnitude of injuries caused by DWH oil (and the associated response efforts)? For a given resource, what was the spatial and temporal extent of injuries? How severe were the injuries, at any level of biological organization (e.g. suborganismal, individual, population)? How long will it take for the resources to recover?

After evaluating oil fate and transport, and the injuries that oil exposure caused to numerous organisms and habitats, the Trustees developed a restoration plan that describes the types of projects that will offset the injuries that DWH oil, dispersants, and response activities caused to natural resources (DWH NRDA Trustees 2016). The plan will be implemented via an $\$ 8.8$ billion settlement. Specific restoration projects for marine mammals and their habitats will be designed and implemented over the next 2 decades.

\section{UNIQUE NATURE OF THIS MARINE MAMMAL NRDA}

While assessing exposure and injuries to any resource in the wake of an environmental disaster is difficult, a Gulf-wide investigation of marine mammals poses a particularly burdensome set of logistical, regulatory, and ethical challenges. Marine mammals are large, long-lived species that can be difficult to find and track in the open water. In addition, all marine mammals are protected under the Marine Mammal Protection Act (MMPA), and some species are granted further protections under the Endangered Species Act. This greatly limits the 
ability of scientists to conduct controlled laboratory studies demonstrating the toxic effects of oil on marine mammal species. Thus, the NRDA science team had to carefully select and integrate appropriate data from response activities (Wilkin et al. 2017, this Theme Section), field studies, and laboratory studies from the literature and from DWH-specific activities.

Although studies on marine mammals following oil spills are limited, both laboratory and field studies, including science conducted in the wake of the Exxon Valdez oil spill, have documented or inferred the adverse effects of oil to marine mammals and other wildlife species and their habitats (e.g. Peterson 2001, Peterson et al. 2003). While data are sparse, both field and laboratory studies have shown that cetaceans exposed to oil can suffer long-term impaired health, and potentially die as a result of that exposure (Geraci \& St. Aubin 1982, 1985, Engelhardt 1983, Matkin et al. 2008). Inference about the impacts of oil exposure on the health of cetaceans is more commonly drawn from the results of laboratory studies on the effects of oil in other marine mammals (e.g. pinnipeds) (Engelhardt 1983) and surrogate mammalian species such as mink Mustela vison (Mazet et al. 2000, 2001, Schwartz et al. 2004, Mohr et al. 2008, 2010).

To address gaps in the marine mammal oil toxicology literature, as well as specific issues related to DWH and the nGoM, the Trustees developed a suite of studies to assess the extent of DWH oil exposure to nGoM cetaceans and to identify and characterize potential exposure and injuries to these animals as a result of the oil spill (Box 1). The Trustees also attempted to investigate injuries to manatees; however, while response workers did respond to manatees in contaminated waters (Wilkin et al. 2017), the Trustees ultimately did not have adequate information on exposure or injury to pursue injury quantification for these mammals. Thus, the discussion here of the impacts of DWH oil on marine mammals refers specifically to the impacts on cetaceans.

As the spill progressed and DWH oil entered Barataria Bay and Mississippi Sound, scientists collected as much data as possible on bottlenose dolphins Tursiops truncatus in these oiled habitats. These stocks were a good starting point for assessing and quantifying injury to nGoM cetaceans because:

- A reasonable amount of biological and ecological data are available for these areas, including environmental data, oil exposure data, and information on other affected resources/species beyond marine mammals
- These areas had established stranding response networks and other support elements (and therefore mortalities from these stocks were more likely to be recovered compared to offshore stocks)

- NRDA-specific data could be integrated with stranding response data, including temporal/spatial analysis of strandings, necropsy findings, and tissue analysis

- It was logistically feasible to conduct assessments (including live captures for health assessments) in these areas compared to other more remote locations

- There are reasonable reference datasets from dolphins in the southeastern USA (e.g. Sarasota Bay) for comparison.

By developing an in-depth analysis of these populations and comparing them to populations that were not exposed to DWH oil, such as those in Sarasota Bay, the NRDA science team could reasonably use the Barataria Bay and Mississippi Sound stocks as case studies for inferring exposure and injuries to other nGoM cetacean stocks. The MMPA defines a stock as 'a group of marine mammals of the same species or smaller taxa in a common spatial arrangement, that interbreed when mature' (16 U.S.C. 1362 [3]). For the purposes of the DWH NRDA, the marine mammal science team assessed injuries by stock. Generally, the team lim-

Box 1. Deepwater Horizon (DWH) marine mammal assessment activities. Source: DWH NRDA Trustees (2016)

\begin{tabular}{|c|}
\hline Oceanic species \\
• Research cruises \\
$\cdot$ Distribution \\
$\cdot$ Exposure \\
$\cdot$ Demographics \\
$\cdot$ Prey availability \\
- Remote biopsies \\
- Tagging \\
- Passive acoustic monitoring \\
Coastal species \\
- Aerial surveys \\
$\cdot$ Distribution \\
$\cdot$ Abundance \\
- Prey availability \\
Bay, sound, and estuary species \\
- Longitudinal photo-identification (ID) \\
$\cdot$ Survival \\
$\cdot$ Abundance \\
- Remote biopsies \\
- Capture-release \\
$\cdot$ Health assessment \\
$\cdot$ Satellite tagging \\
- Stranding investigation
\end{tabular}


its the use of the term 'population' to analyses associated with the population models described in Schwacke et al. (2017, this Theme Section) and DWHMMIQT (2015).

\section{CETACEAN EXPOSURE TO DWH OIL}

As DWH oil spread throughout the nGoM, response workers, scientists, and media outlets documented cetaceans swimming through the oil (Aichinger Dias et al. 2017, this Theme Section). Occasionally, stranding networks were able to collect oil samples from carcasses, and chemical fingerprinting of those samples matched DWH oil (although without additional studies, the Trustees could not confirm whether the oil exposure occurred before or after death). However, most of these observations were opportunistic because it was infeasible to design and implement an allencompassing assessment of cetacean exposure to DWH oil throughout the entire area of the nGoM where DWH oiling occurred. Rather, scientists inferred the spatial and temporal extent of DWH oil exposure to nGoM cetaceans using oil slick observations, and fate and transport models of DWH oil, combined with the historical distributions of each cetacean species (DWHMMIQT 2015). Finally, veterinarians developed scenarios based on the expected exposure conditions in the field to identify and characterize the potential toxicological effects of DWH oil to cetaceans, ruling out alternative causes for the observed adverse health effects (Schwacke et al. 2014, Lane et al. 2015, Smith et al. 2017, this Theme Section). By considering unique aspects of cetacean physiology and behavior (e.g. respiratory system and diving physiology/ behavior) and the toxic effects of oil components (e.g. polycyclic aromatic hydrocarbons [PAHs]) described in the literature, the NRDA science team established plausible and likely links between the release of DWH oil into the nGoM and the increased mortality and adverse health effects observed in coastal common bottlenose dolphins (Fig. 1) (DWH NRDA Trustees 2016), after ruling out other causes of lesions, illnesses, and deaths (Venn-Watson et al. 2015c).

\section{Cetaceans in the surface oil footprint}

The DWH surface oil footprint overlapped with the known ranges of 21 species of nGoM cetaceans, based on population ranges established by satellite tag/radio tracking, acoustic monitoring, and aerial/ vessel surveys (Waring et al. 2013, Aichinger Dias et al. 2017). Cetaceans potentially exposed to the oil included 13 separate stocks of bottlenose dolphins, plus 18 stocks of other dolphin and whale species. In estuarine nGoM waters, where many of the bay, sound, and estuary (BSE) bottlenose dolphin stocks spend time, there was an estimated 15600 square-kilometerdays of floating surface oil (the sum of the daily areal extent over approximately $100 \mathrm{~d}$ ). This floating oil washing into BSE habitats resulted in approximately $2100 \mathrm{~km}$ of shoreline with observed oil. Barataria Bay and Mississippi Sound were 2 BSE areas that were heavily oiled (DWH NRDA Trustees 2016).

Although cetaceans can move large distances and have, in some controlled captive cetacean studies, demonstrated an ability to avoid surface oil (Geraci et al. 1983), one field study suggested that although they can detect oil, they do not consistently avoid it (Smultea \& Würsig 1995). Regardless of their ability to avoid oil if they sense it, the DWH oil spill was so extensive in time and space (Box 2) that it was inevitable that cetaceans were exposed (see the photo-

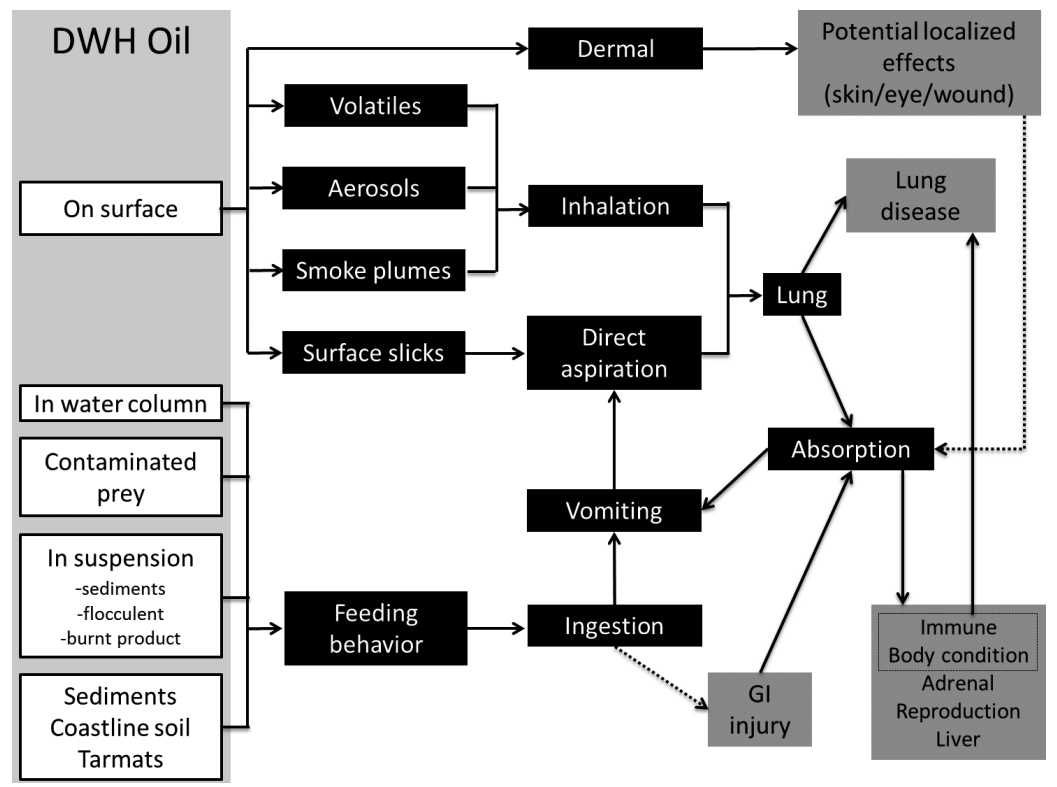

Fig. 1. Conceptual model of Deepwater Horizon (DWH) oil exposure routes in nearshore environments, and how that exposure of bottlenose dolphins Tursiops truncatus was consistent with the observed injuries. The diagram starts with route of oil exposure (white boxes), then moves to the specific mobilization and exposure scenarios for cetaceans (black boxes), and finally to the most likely adverse health effects (grey boxes) 
Box 2. Extent of Deepwater Horizon (DWH) oil contamination. Source: DWH NRDA Trustees (2016)

- $>112000 \mathrm{~km}^{2}$ of the ocean surface

- $>2100 \mathrm{~km}$ of shoreline

- $>1000 \mathrm{~km}^{2}$ of the deep sea floor

- $>400 \mathrm{~km}$ plumes in deep ocean water

graphs, videos, and data collections presented in Aichinger Dias et al. 2017). Aerial/vessel surveys and reports from response monitoring activities from April to September 2010 documented over 1100 cetaceans from at least 10 species in thick surface oil or surface oil sheen (Aichinger Dias et al. 2017, Wilkin et al. 2017).

\section{Routes of exposure and unique anatomical/ physiological considerations}

DWH oil contaminated the air and waters throughout the nGoM from the deep ocean release point, spreading throughout the water column, forming extensive surface slicks, releasing aerosols and vapors above the surface slick, mixing across the shelf and into estuaries, and finally being deposited on marshes and beaches along the coast. Cetaceans use all of these habitats. Characterizing the potential exposure of nGoM cetaceans to DWH oil is complicated by the variety of habitat preferences, feeding strategies, and geographic ranges of each species and stock. Animals likely experienced heterogeneous combinations of exposures from contaminated air, water, and sediment via inhalation, ingestion, aspiration, and adsorption. For example, bottlenose dolphins in Barataria Bay likely inhaled, ingested, aspirated, and came into direct contact with intermittent pulses of weathered surface oil. However, oceanic animals closer to the wellhead were likely exposed to a more constant flow of fresher oil from the broken riser pipe.

\section{Inhalation}

The toxic effects of inhaling petroleum-derived chemicals are well-documented in mammalian laboratory studies, human case studies, and human occupational health studies (e.g. ATSDR 1999). Inhalation exposures were a concern for any air-breathing organisms (e.g. sea turtles, mammals, birds, humans) near the DWH surface slick. Cetaceans breathing just above the air/water interface would likely be more consistently exposed to the highest concentrations of surface oil droplets, volatile organic compounds (VOCs), or aerosolized oil compounds than either birds or humans. Similarly, the unique cetacean physiological and anatomical adaptations for respiratory efficiency associated with diving would increase the impacts of oil inhalation and aspiration.

Cetaceans have deep lung air exchange (80 to $90 \%$ of their lung volume compared to 10 to $20 \%$ for humans). Some species can hold their breath for as long as $2 \mathrm{~h}$ during deep dives, resulting in a greater magnitude and duration of exposure to inhaled toxic chemicals (Irving et al. 1941, Ridgway et al. 1969, Green 1972, Ridgway 1972, Schorr et al. 2014). They also lack turbinates that filter air en route to the lungs, and they have an extensive blood supply in their lungs, facilitating absorption of toxicants into the blood. Depending on the lungs' ability to metabolize toxicants (Roth \& Vinegar 1990), absorption of toxicants by the lungs may be more detrimental than ingestion and absorption via the gastrointestinal (GI) tract, because blood from the lungs moves directly to the heart and then is pumped to the rest of the body before passing through the liver for detoxification (Fig. 2). The physical effects of oil on the surface of the lungs could also reduce gas exchange and damage tissues, leading to other injuries (Stabenau et al. 2006).

Oil constituents in a surface slick can evaporate into the air based on a variety of physical and chemical parameters at the air-water interface. Compounds can be categorized by evaporation rates, ranging from

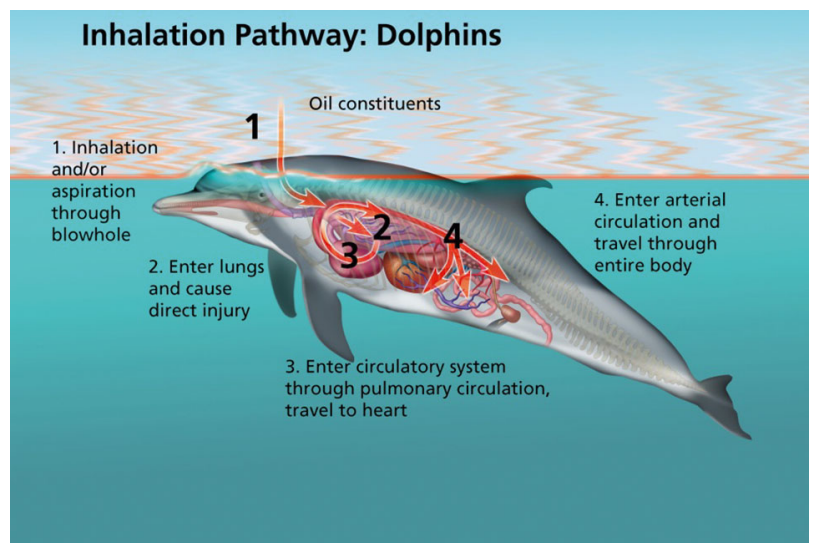

Fig. 2. Transport of oil constituents through a cetacean's body after inhalation into the respiratory tract, leading to absorption into the blood at the lungs, which is then pumped to the rest of the body via the heart, notably bypassing the liver's detoxification process. If dolphins incidentally aspirate liquid oil, it can be especially harmful as a physical irritant. Illustration by Kate Sweeney; originally published in DWH NRDA Trustees (2016) 
semivolatile organic compounds (SVOCs) to VOCs (de Gouw et al. 2011, Stout 2015). For the DWH oil spill, many of the VOCs released at depth either dissolved into the water column or evaporated from the surface very quickly (Ryerson et al. 2011). However, atmospheric particulate matter can form following evaporation and atmospheric oxidation due to new particle nucleation and/or scavenging onto pre-existing aerosols (de Gouw et al. 2011). This process led to increases in secondary organic aerosol mass, generated mostly from $\mathrm{C} 12$ to $\mathrm{C} 16$ hydrocarbons (which includes 2- and 3-ring PAHs) evaporating from the broader surface slick footprint, where cetaceans would be exposed as they surfaced to breathe.

BP contractors collected a large number of measurements on the personal airborne exposure of oil spill response/clean-up workers and scientists to total hydrocarbons. Results from a subset of the dosimeter badges indicated that workers in Louisiana were exposed to average total hydrocarbon levels 2 to 4 times higher than similar workers in Florida over the period of 20 April through 10 August, and substantially more than background levels prior to the spill (Stewart et al. 2017). This analysis was limited to the subset of individuals working on small vessels working near the shoreline that were not involved in decontamination activities, because these most closely mimicked potential dolphin exposure. On 24 May 2010 near Barataria Bay, a stranding response team was able to collect tissue samples, including lung tissue, from a relatively fresh bottlenose dolphin carcass subsequently shown through chemical fingerprinting to have DWH oil on its skin. The lung tissue contained VOC/SVOCs consistent with an inhaled dose, rather than aspirated liquid oil (Stout 2015), which indicates that the animal was exposed to airborne oil compounds prior to death.

Disruptions to the air-water interface can create small droplets with oil and water, which can become indefinitely suspended in the air column (primary aerosols) (Murphy et al. 2015). Whether as volatiles or aerosols, cetaceans can be exposed to oil components in the air column near the air-water interface. Upon surfacing after a long dive, cetaceans exhale through their blowhole, with sufficient energy to produce a cloud of seawater droplets (promoting volatilization) that can then be inhaled while the animals recover their oxygen supply. Similar aerosols can be generated by waves, wind, and rain, both in the presence and absence of oil - the application of dispersants increases the escape rate and decreases the size of the droplets (Ehrenhauser et al. 2014, LiyanaArachchi et al. 2014, Murphy et al. 2015).

\section{Aspiration}

Cetaceans may incidentally draw seawater, and presumably floating oil, into their lungs by breathing in splashed droplets or liquid that has collected near the blowhole just prior to inhalation. Aspiration of liquid oil can cause physical injuries to the respiratory tract by irritating tissues/membranes (Gentina et al. 2001). This can also lead to absorption of toxicants into the blood, as in inhalation exposure (Fig. 2) (Coppock et al. 1995, 1996, Prasad et al. 2011). In other mammals such as cattle, for example, petroleum aspiration can lead to severe inflammatory response and lung disease, including pneumonia, fibrosis, and pulmonary dysfunction (Coppock et al. 1995, 1996).

\section{Ingestion}

During the DWH incident, cetaceans hunting and capturing prey near oil slicks would have been at risk of ingesting petroleum components. Cetaceans have many different feeding behaviors, including straining water for krill, suction feeding on fish/cephalopods, fish herding, and drilling on crabs/benthic fish (Rossbach \& Herzing 1997, Werth 2000). During highly active feeding, a cetacean could be more likely to drive entrainment of surface oil into the water column or disturb buried oil in sediments, making the oil more available for incidental or direct ingestion. Dolphins may consume 4.5 to $13 \mathrm{ml} \mathrm{kg}^{-1}$ of seawater a day as they seek and consume prey (Telfer et al. 1970, Hui 1981); thus dolphins foraging in oil-contaminated waters during the DWH spill would likely have ingested oil. Oil ingestion can cause GI tract mucosal irritation, vomiting, and regurgitation (Rowe et al. 1973, Edwards 1989). Unlike toxicant absorption through the lungs, toxicant absorption into the blood across the stomach and intestinal tissues may be subject to first-pass metabolism in the liver (Fig. 3). Bodkin et al. (2012) reported that sea otters Enhydra lutris suffered a variety of long-term effects from the Exxon Valdez oil spill due to ingestion during intertidal foraging and the presence of oil near otter foraging pits (the authors ruled out exposure by inhalation).

However, ingestion of oil may also lead to impacts on the cetacean lung. Humans and cattle that ingest petroleum (e.g. through ingestion of contaminated water) usually experience nausea and vomiting and are at risk of aspirating oily vomitus into the lungs (Coppock et al. 1995, 1996, Lifshitz et al. 2003, Siddiqui et al. 2008, Sen et al. 2013) (Fig. 3 inset). Aspirating vomitus can cause pneumonia and, in some 


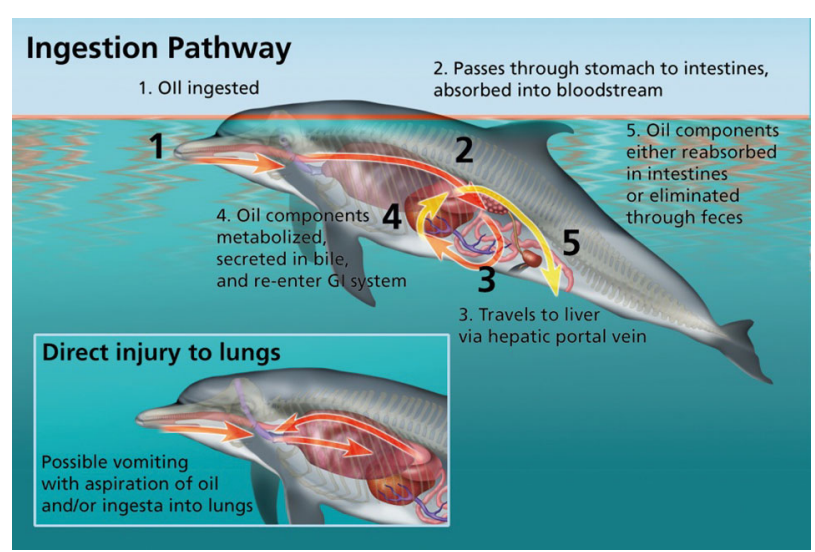

Fig. 3. Transport of oil constituents through a cetacean's body after ingestion into the gastrointestinal (GI) tract, leading to some absorption into the blood but also detoxification through the liver. Animals that ingest oil also may become nauseous and vomit oil and ingesta, which may be aspirated into the lungs (inset). Illustration by Kate Sweeney; originally published in DWH NRDA Trustees (2016)

cases, may lead to lung abscesses and infections (Coppock et al. 1995, 1996). Venn-Watson et al. (2015a) linked aspiration pneumonia, lung abscesses, and pulmonary infections in bottlenose dolphins to exposure to DWH oil.

\section{Dermal contact}

Although cetaceans have a thick epidermis, lesions, rake marks, or abrasions may create vulnerable areas where oil could be absorbed and cause toxic effects to underlying tissues, especially in combination with other stressors, such as infectious bacteria, viruses, or parasites. Oil exposure also has the potential to irritate and denude mucus membranes such as the eyes and mouth (Dutton 1934, Hansbrough et al. 1985).

\section{Characterizing cetacean injuries from DWH oil spill}

To assess injuries to cetaceans as part of the NRDA, the Trustees conducted population studies and feasible and timely health assessments for some exposed stocks of bottlenose dolphins, to analyze causal factors for mortality from the high number of post-spill strandings. From 2010 to 2014, the NOAA tracked a cetacean unusual mortality event (UME) in the nGoM (NOAA 2016). In reviewing the UME data, scientists identified several distinct clusters of strandings (Litz et al. 2014, Venn-Watson et al. 2015b): a cluster of deaths resulting from cold temperatures and low salinity in Lake Pontchartrain, Louisiana and western Mississippi Sound in early 2010; a large number of deaths in southern Louisiana (centered on Barataria Bay) from 2010 to 2011 and a cluster with unusually high numbers of perinates in Mississippi and Alabama in 2011, both of which were attributed to DWH oil (see below); and a Gulf-wide cluster in early 2013 (the authors did not opine on the cause of the 2013 cluster because of insufficient data; Venn-Watson et al. 2015b).

Several studies examined the likelihood that the UME clusters in southern Louisiana and Mississippi/ Alabama in 2010 and 2011 were the result of the DWH spill. Dolphin health evaluations conducted in Barataria Bay found a high prevalence of pulmonary disease, compromised stress response, and reproductive failure (Schwacke et al. 2014, Lane et al. 2015). Scientists conducting necropsies found a high prevalence of lung and adrenal lesions in dead dolphins within the DWH oil spill footprint (Venn-Watson et al. 2015a). Combined evidence from statistical analysis of the strandings clusters (Venn-Watson et al. 2015b), necropsy data from the strandings (Venn-Watson et al. 2015a, Colegrove et al. 2016), and findings from live health assessments conducted in Barataria Bay following the spill (Schwacke et al. 2014, Lane et al. 2015) linked these adverse health effects to exposure to the DWH oil after examining and ruling out other potential causes.

This Theme Section contains additional papers on the adverse effects described in the previously reported studies and the PDARP/PEIS. Interestingly, although the prevalence of some of the adverse health effects seen in Schwacke et al. (2014) has declined, other symptoms of oil exposure in dolphins still linger in Barataria Bay, including pulmonary abnormalities and an impaired stress response. These lingering health effects continue in at least one other site (Mississippi Sound) within the oil spill footprint (Smith et al. 2017). DWH oil exposure can result in immune system dysregulation (De Guise et al. unpubl.), which is consistent with the increased susceptibility of perinates to in utero Brucella infection (Colegrove et al. 2016). Kellar et al. (2017, this Theme Section) provide a deeper analysis of the reproductive failures seen in bottlenose dolphins in Louisiana, Mississippi, and Alabama, including a synthesis of hormone data from remote biopsy samples and surgical biopsies from dolphins sampled via capture-release health assessments, as well as vessel surveys of animals in photoID studies.

Throughout the assessment, scientists considered and designed studies to evaluate all feasible expla- 
nations for the observed injuries to cetaceans. By weighing the plausibility, specificity, consistency, and strength of association among the data, the team developed a rigorous, scientifically defensible basis for a causal relationship between the DWH incident and the injuries to cetaceans in the nGoM (VennWatson et al. 2015c).

Scientists investigated other factors that have contributed to cetacean UMEs in the past, including biotoxins from harmful algal blooms, human/fishery interactions, infectious disease outbreaks (e.g. morbillivirus, Brucella), extreme environmental conditions (e.g. cold weather, low salinity), and non-DWHrelated chemical contamination, before concluding that DWH oil exposure caused cetacean injuries. For example, Fauquier et al. (2017, this Theme Section) investigated the relationship between the increased strandings and morbillivirus outbreaks in the nGoM - just one example of how the NRDA science team took alternative hypotheses into consideration.

\section{Quantifying DWH cetacean injuries}

The increases in mortality, reproductive failure, and adverse health effects represent a limited view of how DWH oil exposure impacted bottlenose dolphin stocks in Barataria Bay and Mississippi Sound in the few years immediately following the spill. They do not capture the cumulative effect of the injuries on these populations, nor do they represent the entire scope of the DWH oil spill injury to each population into the future.

The NRDA science team conducted a coordinated set of studies to characterize and quantify injuries to the Barataria Bay and Mississippi Sound bottlenose dolphin stocks (Fig. 4). The coordinated studies were designed to provide necessary inputs to parameterize a population model (Schwacke et al. 2017) for both stocks that compared their expected population trajectories (assuming the DWH spill had not occurred) to the post-DWH trajectories. These trajectories were influenced by increased mortality, de-

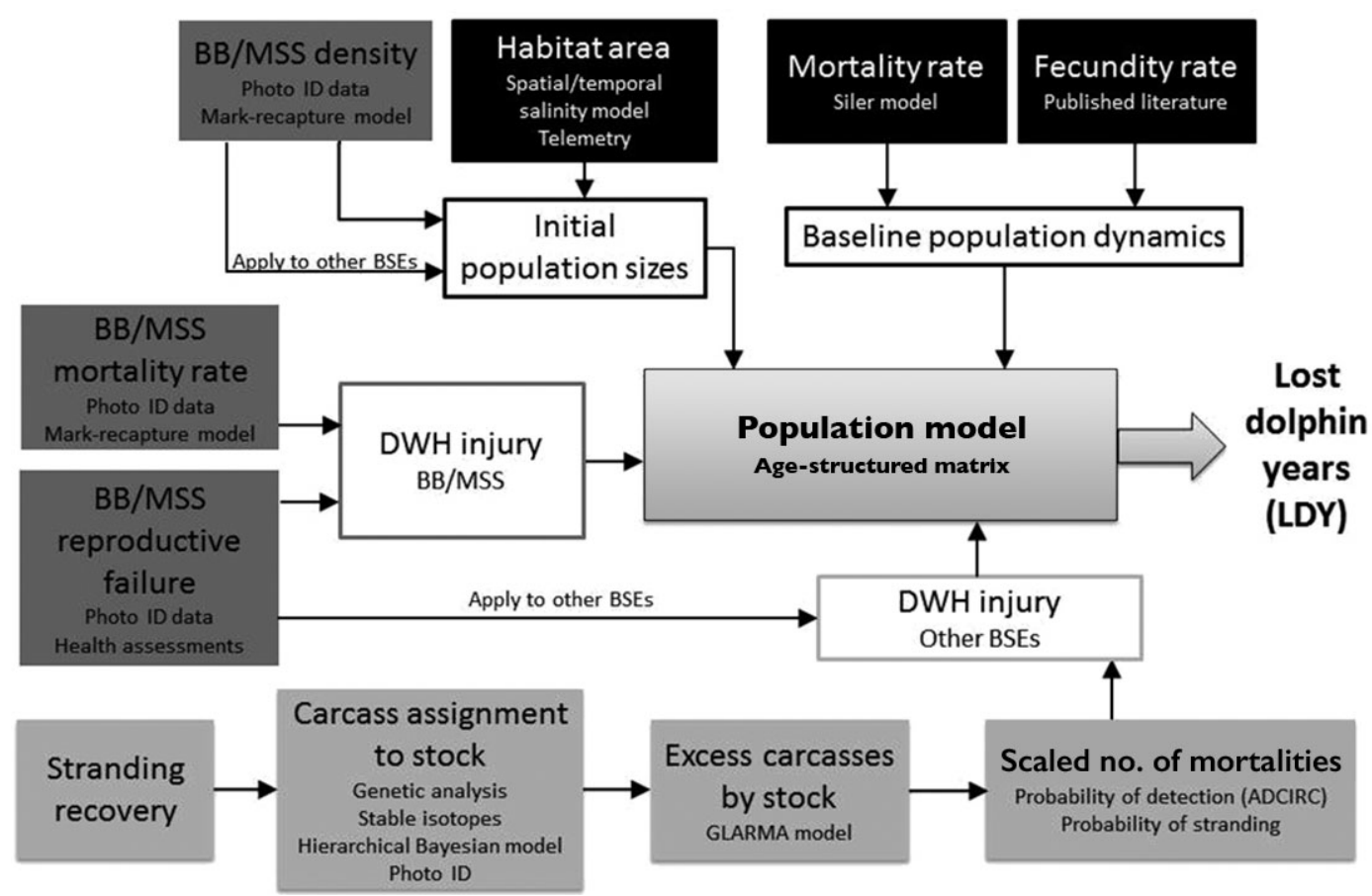

Fig. 4. A variety of field data, historical data, and statistical models/analyses were combined to create population models that quantified how Deepwater Horizon (DWH) oil changed population trajectories for each stock that was exposed. Baseline data (black boxes) were used to help predict what each population's trajectory would have been if the DWH oil spill had not occurred. The Barataria Bay (BB) and Mississippi Sound (MSS) stock populations had higher levels of mortality and reproductive failure because of exposure to DWH oil (dark grey boxes). The injury information from BB and MSS was combined with data and modeling efforts to estimate the injuries to other bottlenose dolphin bay, sound, and estuary (BSE) stocks. For each stock, a population model based on an age-structured matrix was run to determine the number of dolphins lost each year (lost dolphin years) because of the effects of DWH oil. Most of the studies and analyses in this diagram are described further in the papers in this Theme Section. For anything else (e.g. Siler model), please refer to DWH NRDA Trustees (2016) and DWHMMIQT (2015). GLARMA: generalized linear autoregressive moving average; ADCIRC: advanced circulation model (www.adcirc.org) 
creased reproduction, and increased adverse health effects resulting from DWH oil exposure. To establish post-spill population vital rates (i.e. survival and reproductive success), the NRDA science team conducted photo-ID surveys and performed markrecapture analyses in Barataria Bay (Kellar et al. 2017, McDonald et al. 2017, this Theme Section) and Mississippi Sound (DWHMMIQT 2015, DWH NRDA Trustees 2016, Kellar et al. 2017). In addition, the NRDA science team analyzed bottlenose dolphin spatial preferences (Wells et al. 2017, this Theme Section) and the density of dolphins within different habitat strata (e.g. near barrier islands vs. inside the bays) (McDonald et al. 2017). To appropriately estimate the total population of each stock as an input for the population model, the team extrapolated from the numbers of dolphins estimated across habitat strata within the photo-ID survey areas (McDonald et al. 2017) to the number of dolphins within the entire stock area using spatial modeling bounded by salinity gradients to estimate the bottlenose dolphins' likely habitat area (Hornsby et al. 2017, this Theme Section).

After estimating population-level injuries in Barataria Bay and Mississippi Sound, the NRDA science team needed a plausible model to estimate the severity and extent of injuries to other stocks across the nGoM. In the majority of these other stocks, injury data were limited to those collected from the investigation of dead strandings. Given the increased strandings numbers, how could the scientists (1) identify the stock to which each of the carcasses belonged (e.g. BSE vs. northern coastal); (2) determine how much of the observed mortality was associated with the DWH oil; and (3) translate the number of observed strandings to an estimate of the number of actual mortalities, knowing that the vast majority of carcasses are never observed? To address the first question, Thomas et al. (2017, this Theme Section) developed a hierarchical Bayesian model to assign stranded carcasses to BSE or coastal stocks using both genetic data (Rosel et al. 2017, this Theme Section) and stable isotope data (Hohn et al. 2017, this Theme Section).

The NRDA science team then used a generalized linear autoregressive moving average (GLARMA) model to evaluate the observed strandings in each BSE to determine the deviation from annual and seasonal trends in relation to the degree of surface oiling over time, including consideration for abnormally cold temperatures (these analyses are not described in this Theme Section, but are available in DWHMMIQT 2015). These DWH oil exposure-related excess observed strandings (by stock) were then scaled to an estimated total number of excess mortalities using models to correct for carcass beaching and recovery efficiencies, including a carcass drift model (DWHMMIQT 2015). Finally, Schwacke et al. (2017) and DWHMMIQT (2015) used results from all of these analyses to estimate how DWH oil-related injuries combined to impact the trajectory of each stock's population.

Cetaceans are long-lived, slow-maturing species. Thus, populations have difficulty recovering from the loss of reproductive adults, whether from premature death or a decrease in reproductive success. The population model, applied separately to 9 BSE and 2 coastal bottlenose dolphin stocks, allowed consideration of long-term impacts resulting from immediate losses and reproductive failures in the few years following the spill, as well as expected persistent impacts on survival and reproduction for exposed animals well into the future. While the focus of this Theme Section is on the effects of the DWH oil spill on bottlenose dolphin stocks, the NRDA science team used a similar approach to quantify injuries to other cetacean stocks in the nGoM, using spatial comparisons of each stock with the DWH oil footprint and integrating mortality and reproductive failure estimates into a population model for each stock (DWHMMIQT 2015).

\section{CONCLUSIONS}

The cetacean investigations following the DWH incident provided an example of how scientists (from state and federal government agencies, academics, nonprofit organizations, and the private sector) and decision-makers can mobilize and coordinate to respond to a major environmental disaster and assess its impacts. Despite the uncertainties involved in working at such large scales over time and space, and the restrictions associated with studying marine mammals, the studies described here form a coherent story of exposure (via inhalation, ingestion, and aspiration of DWH oil) and injury (including mortality, reproductive failure, and adverse effects on lung and the hypothalamus-pituitary-adrenal axis).

Oil from the DWH blowout contaminated the water, air, sediments, and prey in the nGoM. The footprint of the surface slick overlapped with 31 stocks of cetaceans, likely resulting in inhalation, ingestion, and aspiration of toxic oil components. Exposure to oil over similar ranges of time, magnitude, and biological pathways has been shown to be toxic to a 
variety of animals (including humans) both in laboratory and field studies (e.g. Engelhardt 1983, Goldstein et al. 2011, DWH NRDA Trustees 2016 Section 4.3). The wide range of adverse health effects and increased mortality/reproductive failure observed in cetacean populations throughout the nGoM over the last 6 yr are consistent with the exposure scenarios described here (Schwacke et al. 2014, Venn-Watson et al. 2015a, Colegrove et al. 2016, Smith et al. 2017).

Each of the animals and their unique injuries constitute a basis for action under the NRDA process; however, the NRDA science team was also able to use statistical approaches and models to better describe how the injuries to individual animals will impact the population status and dynamics into the future. While many of these studies have now been published here and elsewhere, a true understanding of the long-term effects of DWH oil contamination (and the associated response activities) on nGoM marine mammals will require sustained investigation and monitoring.

Acknowledgements. We thank the very large team of technical experts, stranding networks, Trustee representatives, and case support that contributed to the marine mammal assessment. Although the number of people and organizations that collected and analyzed samples/data is too large to capture here, we are very grateful to each of you for your contributions. We encourage the reader to reference the individual papers in this Theme Section for a more complete list of the scientists and organizations associated with each of these studies. The studies described here were conducted as part of the DWH NRDA and included scientists funded through NOAA, other federal and state Trustees, and BP PLC. The John H. Prescott Marine Mammal Rescue Assistance Grant Program and the Marine Mammal Health and Stranding Response Program provided funding for this work in addition to the funding from the DWH NRDA. The scientific results and conclusion of this publication, as well as any views or opinions expressed herein, are those of the authors and do not necessarily represent the view of NOAA or any other natural resource Trustee for the DWH NRDA.

\section{LITERATURE CITED}

Aichinger Dias L, Litz J, Garrison L, Martinez A, Barry K, Speakman T (2017) Exposure of cetaceans to petroleum products following the Deepwater Horizon oil spill in the Gulf of Mexico. Endang Species Res 33:119-125

ATSDR (Agency for Toxic Substances and Disease Registry) (1999) Toxicological profile for total petroleum hydrocarbons (TPH). Agency for Toxic Substances and Disease Registry, US Department of Health and Human Services, Public Health Service, Atlanta, GA

Bodkin JL, Ballachey BE, Coletti HA, Esslinger GG and others (2012) Long-term effects of the 'Exxon Valdez' oil spill: sea otter foraging in the intertidal as a pathway of exposure to lingering oil. Mar Ecol Prog Ser 447: 273-287
Colegrove KM, Venn-Watson S, Litz J, Kinsel MJ and others (2016) Fetal distress and in utero pneumonia in perinatal dolphins during the northern Gulf of Mexico unusual mortality event. Dis Aquat Org 119:1-16

Coppock RW, Mostrom MS, Khan AA, Semalulu SS (1995) Toxicology of oil field pollutants in cattle: a review. Vet Hum Toxicol 37:569-576

Coppock RW, Mostrom MS, Stair EL, Semalulu SS (1996) Toxicopathology of oilfield poisoning in cattle: a review. Vet Hum Toxicol 38:36-42

de Gouw JA, Middlebrook AM, Warneke C, Ahmadov R and others (2011) Organic aerosol formation downwind from the Deepwater Horizon oil spill. Science 331: 1295-1299

De Guise S, Levin M, Gebhard E, Jasperse L and others (2017) Changes in immune functions in bottlenose dolphins in the northern Gulf of Mexico associated with the Deepwater Horizon oil spill. Endang Species Res (in press) doi:10.3354/esr00814

Dutton WF (1934) Petroleum dermatitis. Med Rec 140:550-552

DWH NRDA (Deepwater Horizon Natural Resource Damage Assessment) Trustees (2016) Deepwater Horizon oil spill programmatic damage assessment and restoration plan and programmatic environmental impact statement. www.gulfspillrestoration.noaa.gov/restoration-planning/ gulf-plan/ (accessed 9 Sept 2016)

DWHMMIQT (Deepwater Horizon Marine Mammal Injury Quantification Team) (2015) Models and analyses for the quantification of injury to Gulf of Mexico cetaceans from the Deepwater Horizon oil spill. DWH NRDA Marine Mammal Technical Working Group Report. Prepared for National Oceanic and Atmospheric Administration

Edwards WC (1989) Toxicology of oil field wastes. Hazards to livestock associated with the petroleum industry. Vet Clin North Am Food Anim Pract 5:363-374

Ehrenhauser FS, Avij P, Shu X, Dugas V and others (2014) Bubble bursting as an aerosol generation mechanism during an oil spill in the deep-sea environment: laboratory experimental demonstration of the transport pathway. Environ Sci Process Impacts 16:65-73

Engelhardt FR (1983) Petroleum effects on marine mammals. Aquat Toxicol 4:199-217

Fauquier DA, Litz J, Sanchez S, Colegrove K and others (2017) Evaluation of morbillivirus exposure in cetaceans from the northern Gulf of Mexico 2010-2014. Endang Species Res 33:211-220

KGentina T, Tillie-Leblond I, Birolleau S, Faycal S and others (2001) Fire-eater's lung: seventeen cases and a review of the literature. Medicine 80:291-297

Geraci JR, St. Aubin DJ (1982) Study of the effect of oil on cetaceans, final report. Department of the Interior, Bureau of Land Management, New York, NY

Geraci JR, St. Aubin DJ (1985) Expanded studies of the effects of oil on cetaceans, final report. Part I. US Department of the Interior, Minerals Management Service, Washington, DC

*Geraci JR, St. Aubin DJ, Reisman RJ (1983) Bottlenose dolphins, Tursiops truncatus, can detect oil. Can J Fish Aquat Sci 40:1516-1522

* Goldstein BD, Osofsky HJ, Lichtveld MY (2011) The Gulf oil spill. N Engl J Med 364:1334-1348

Green RF (1972) Observations of the anatomy of some cetaceans and pinnipeds. In: Ridgway SH (ed) Mammals of the sea: biology and medicine. Charles C. Thomas Publishers, Springfield, IL, p 247-297 
Hansbrough JF, Zapata-Sirvent R, Dominic W, Sullivan J, Boswick J, Wang XW (1985) Hydrocarbon contact injuries. J Trauma 25:250-252

*Hohn AA, Thomas L, Carmichael RH, Litz J and others (2017) Assigning stranded bottlenose dolphins to source stocks using stable isotope ratios following the Deepwater Horizon oil spill. Endang Species Res 33:235-252

Hornsby FE, McDonald TL, Balmer BC, Speakman TR and others (2017) Using salinity to identify common bottlenose dolphin habitat in Barataria Bay, Louisiana, USA. Endang Species Res 33:181-192

Huguenin MT, Haury DH, Weiss JC, Helton D, Manen CA, Reinharz E, Michel J (1996) Guidance document for natural resource damage assessment under the Oil Pollution Act of 1990. Damage Assessment and Restoration Program, NOAA, Silver Spring, MD

Hui CA (1981) Seawater consumption and water flux in the common dolphin Delphinus delphis. Physiol Zool 54: $430-440$

Irving L, Scholander PF, Grinnell SW (1941) The respiration of the porpoise, Tursiops truncatus. J Cell Comp Physiol $17: 145-168$

Kellar NM, Speakman TR, Smith CR, Lane SM and others (2017) Low reproductive success rates of common bottlenose dolphins Tursiops truncatus in the northern Gulf of Mexico following the Deepwater Horizon disaster (2010-2015). Endang Species Res 33:143-158

Lane SM, Smith CR, Mitchell J, Balmer BC and others (2015) Reproductive outcome and survival of common bottlenose dolphins sampled in Barataria Bay, Louisiana, USA, following the Deepwater Horizon oil spill. Proc R Soc B 282:20151944

Lifshitz M, Sofer S, Gorodischer R (2003) Hydrocarbon poisoning in children: a 5-year retrospective study. Wilderness Environ Med 14:78-82

Litz JA, Baran MA, Bowen-Stevens SR, Carmichael RH and others (2014) Review of historical unusual mortality events (UMEs) in the Gulf of Mexico (1990-2009): providing context for the multi-year northern Gulf of Mexico cetacean UME declared in 2010. Dis Aquat Org 112: 161-175

Liyana-Arachchi TP, Zhang Z, Ehrenhauser FS, Avij P, Valsaraj KT, Hung FR (2014) Bubble bursting as an aerosol generation mechanism during an oil spill in the deep-sea environment: molecular dynamics simulations of oil alkanes and dispersants in atmospheric air/salt water interfaces. Environ Sci Process Impacts 16:53-64

Matkin CO, Saulitis EL, Ellis GM, Olesiuk P, Rice SD (2008) Ongoing population-level impacts on killer whales Orcinus orca following the 'Exxon Valdez' oil spill in Prince William Sound, Alaska. Mar Ecol Prog Ser 356:269-281

Mazet JK, Gardner IA, Jessup DA, Lowenstine LJ, Boyce WM (2000) Evaluation of changes in hematologic and clinical biochemical values after exposure to petroleum products in mink (Mustela vison) as a model for assessment of sea otters (Enhydra lutris). Am J Vet Res 61: 1197-1203

Mazet JAK, Gardner IA, Jessup DA, Lowenstine LJ (2001) Effects of petroleum on mink applied as a model for reproductive success in sea otters. J Wildl Dis 37:686-692

McDonald TL, Hornsby FE, Speakman TR, Zolman ES and others (2017) Survival, density, and abundance of common bottlenose dolphins in Barataria Bay (USA) following the Deepwater Horizon oil spill. Endang Species Res 33:193-209
Mohr FC, Lasley B, Bursian S (2008) Chronic oral exposure to Bunker $\mathrm{C}$ fuel oil causes adrenal insufficiency in ranch mink (Mustela vison). Arch Environ Contam Toxicol 54: 337-347

* Mohr FC, Lasley B, Bursian S (2010) Fuel oil-induced adrenal hypertrophy in ranch mink (Mustela vison): effects of sex, fuel oil weathering, and response to adrenocorticotropic hormone. J Wildl Dis 46:103-110

* Murphy DW, Li C, d'Albignac V, Morra D, Katz J (2015) Splash behaviour and oily marine aerosol production by raindrops impacting oil slicks. J Fluid Mech 780: 536-577

NOAA (2016) Cetacean unusual mortality event in northern Gulf of Mexico (2010-2014). www.nmfs.noaa.gov/pr/ health/mmume/cetacean_gulfofmexico.htm (accessed 13 June 2016)

Peterson CH (2001) The 'Exxon Valdez' oil spill in Alaska: acute, indirect and chronic effects on the ecosystem. Adv Mar Biol 39:1-103

* Peterson CH, Rice SD, Short JW, Esler D, Bodkin JL, Ballachey BE, Irons DB (2003) Long-term ecosystem response to the Exxon Valdez oil spill. Science 302:2082-2086

* Prasad R, Karmakar S, Sodhi R, Karmakar S (2011) Bilateral hemorrhagic pleural effusion due to kerosene aspiration. Lung India 28:130-132

Ridgway SH (ed) (1972) Mammals of the sea: respiration system. Charles C. Thomas Publishers, Springfield, IL, p 260-264

Ridgway SH, Scronce BL, Kanwisher J (1969) Respiration and deep diving in the bottlenose porpoise. Science 166: 1651-1654

Rosel PE, Wilcox LA, Sinclair C, Speakman TR, Tumlin MC, Litz JA, Zolman ES (2017) Genetic assignment to stock of stranded common bottlenose dolphins in southeastern Louisiana after the Deepwater Horizon oil spill. Endang Species Res 33:221-234

Rossbach KA, Herzing DL (1997) Underwater observations of benthic-feeding bottlenose dolphins (Tursiops truncatus) near Grand Bahama Island, Bahamas. Mar Mamm Sci 13:498-504

Roth RA, Vinegar A (1990) Action by the lungs on circulating xenobiotic agents, with a case study of physiologically based pharmacokinetic modeling of benzo(a)pyrene disposition. Pharmacol Ther 48:143-155

Kowe LD, Dollahite JW, Camp BJ (1973) Toxicity of two crude oils and kerosine to cattle. J Am Vet Med Assoc 162:61-66

Ryerson TB, Aikin KC, Angevine WM, Atlas EL and others (2011) Atmospheric emissions from the Deepwater Horizon spill constrain air-water partitioning, hydrocarbon fate, and leak rate. Geophys Res Lett 38:L07803

Schorr GS, Falcone EA, Moretti DJ, Andrews RD (2014) First long-term behavioral records from Cuvier's beaked whales (Ziphius cavirostris) reveal record-breaking dives. PLOS ONE 9:e92633

Schwacke LH, Smith CR, Townsend FI, Wells RS and others (2014) Health of common bottlenose dolphins (Tursiops truncatus) in Barataria Bay, Louisiana, following the Deepwater Horizon oil spill. Environ Sci Technol 48: 93-103

Schwacke LH, Thomas L, Wells RS, McFee WE and others (2017) Quantifying injury to common bottlenose dolphins from the Deepwater Horizon oil spill using an age-, sex-, and class-structured population model. Endang Species Res 33:265-279 
Schwartz JA, Aldridge BM, Lasley BL, Snyder PW, Stott JL, Mohr FC (2004) Chronic fuel oil toxicity in American mink (Mustela vison): systemic and hematological effects of ingestion of a low-concentration of Bunker C fuel oil. Toxicol Appl Pharmacol 200:146-158

Sen V, Kelekci S, Selimoglu Sen H, Yolbas I, Günes A, Abakay O, Fuat Gurkan M (2013) An evaluation of cases of pneumonia that occurred secondary to hydrocarbon exposure in children. Eur Rev Med Pharmacol Sci 17(Suppl 1):9-12

Siddiqui EU, Razzak JA, Naz F, Khan SJ (2008) Factors associated with hydrocarbon ingestion in children. J Pak Med Assoc 58:608-612

Smith CR, Rowles TK, Hart LB, Townsend FI and others (2017) Slow recovery of Barataria Bay dolphin health following the Deepwater Horizon oil spill (2013-2014), with evidence of persistent lung disease and impaired stress response. Endang Species Res 33:127-142

Smultea MA, Würsig B (1995) Behavioral reactions of bottlenose dolphins to the Mega Borg oil spill, Gulf of Mexico 1990. Aquat Mamm 21:171-181

Stabenau EK, Giczewski DT, Maillacheruvu KY (2006) Uptake and elimination of naphthalene from liver, lung, and muscle tissue in the leopard frog (Rana pipiens). J Environ Sci Health Part A Tox Hazard Subst Environ Eng 41:1449-1461

Stewart PA, Stenzel MR, Ramachandran G, Banerjee S and others (2017) Development of a total hydrocarbon ordinal job-exposure matrix for workers responding to the Deepwater Horizon disaster: the Gulf study. J Exp Sci Environ Epi (in press)

Stout SA (2015) Chemical fingerprinting assessment of exposure of dolphins to Macondo oil during and after the Deepwater Horizon oil spill. US Department of the Interior, Deepwater Horizon Response \& Restoration Admin Record DWH-AR0038954. https://pub-dwhdatadiver.orr. noaa.gov/dwh-ar-documents/946/DWH-AR0038954.pdf

Editorial responsibility: Tracey Goldstein (Guest Editor), Davis, California, USA (accessed 20 Sept 2016)

Telfer N, Cornell LH, Prescott JH (1970) Do dolphins drink water? J Am Vet Med Assoc 157:555-558

* Thomas L, Booth CG, Rosel PE, Hohn A, Litz J, Schwacke LH (2017) Where were they from? Modelling the source stock of dolphins stranded after the Deepwater Horizon oil spill using genetic and stable isotope data. Endang Species Res 33:253-264

*Venn-Watson S, Colegrove KM, Litz J, Kinsel M and others (2015a) Adrenal gland and lung lesions in Gulf of Mexico common bottlenose dolphins (Tursiops truncatus) found dead following the Deepwater Horizon oil spill. PLOS ONE 10:e0126538

Venn-Watson S, Garrison L, Litz J, Fougeres EM and others (2015b) Demographic clusters identified within the northern Gulf of Mexico common bottlenose dolphin (Tursiops truncatus) unusual mortality event: January 2010-June 2013. PLOS ONE 10:e0117248

Venn-Watson S, Colegrove KM, Litz J, Kinsel M and others (2015c) Morbidity and mortality in bottlenose dolphins: summary of alternative hypotheses. DWH Marine Mammal NRDA Technical Working Group Report

Waring GT, Josephson E, Maze-Foley K, Rosel PE (eds) (2013) US Atlantic and Gulf of Mexico marine mammal stock assessments - 2012. NOAA Tech Memo NMFSNE-223

Wells RS, Schwacke LH, Rowles TK, Balmer BC and others (2017) Ranging patterns of common bottlenose dolphins Tursiops truncatus in Barataria Bay, Louisiana, following the Deepwater Horizon oil spill. Endang Species Res 33: $159-180$

Werth AJ (2000) Feeding in marine mammals. In: Schwenk $\mathrm{K}$ (ed) Feeding: form, function and evolution in tetrapod vertebrates. Academic Press, San Diego, CA, p 487-526

*Wilkin SM, Rowles TK, Stratton E, Adimey N and others (2017) Marine mammal response operations during the Deepwater Horizon oil spill. Endang Species Res 33:107-118

Submitted: October 2, 2016; Accepted: January 2, 2017 Proofs received from author(s): January 24, 2017 